\title{
Insulin receptor membrane retention by a traceable chimeric mutant
}

Jimena Giudice ${ }^{1,2,4}$, Elizabeth A Jares-Erijman ${ }^{2^{\wedge}}$ and Federico Coluccio Leskow ${ }^{1,3^{*}}$

\begin{abstract}
Background: The insulin receptor (IR) regulates glucose homeostasis, cell growth and differentiation. It has been hypothesized that the specific signaling characteristics of $I R$ are in part determined by ligand-receptor complexes localization. Downstream signaling could be triggered from the plasma membrane or from endosomes. Regulation of activated receptor's internalization has been proposed as the mechanism responsible for the differential isoform and ligand-specific signaling.

Results: We generated a traceable IR chimera that allows the labeling of the receptor at the cell surface. This mutant binds insulin but fails to get activated and internalized. However, the mutant heterodimerizes with wild type IR inhibiting its auto-phosphorylation and blocking its internalization. IR membrane retention attenuates AP-1 transcriptional activation favoring Akt activation.
\end{abstract}

Conclusions: These results suggest that the mutant acts as a selective dominant negative blocking IR internalization-mediated signaling.

Keywords: Insulin receptor, Membrane retention, Dominant negative, Endocytosis

\section{Background}

Insulin receptor (IR) is a tetrameric tyrosine kinase receptor involved on glucose homeostasis, cell growth and differentiation. Two IR variants are produced in mammals by alternative splicing: IR-A lacking exon 11 and the full length IR-B $[1,2]$. While IR-B is widely expressed in adult tissues, embryos predominantly express IR-A where it functions as a regulator of cellular proliferation and differentiation [3]. Alterations in the ratio of IR isoform expression have been associated with cellular dysregulation and disease. Some reports showed that in diabetic patients there are differences at the mRNA level in the IR-A/IR-B ratio in skeletal muscle $[4,5]$, however this was not observed by others [6-8]. Cancer cells commonly express the IR-A subtype [9-12]. In addition, there are differences in the activation and signaling

\footnotetext{
* Correspondence: federico@fbmc.fcen.uba.ar

Deceased

'Departamento de Química Biológica, Facultad de Ciencias Exactas y Naturales (FCEN), Universidad de Buenos Aires (UBA) IQUIBICEN, CONICET, Intendente Güiraldes 2160, Ciudad Universitaria, C1428EGA Buenos Aires, Argentina

${ }^{3}$ Departamento de Ciencias Básicas, Universidad Nacional de Luján, Buenos Aires, Argentina

Full list of author information is available at the end of the article
}

events between the two isoforms, indicating specific functions [13-15]. Using an elegant harmonic oscillator mathematical model, Knudson et al. reported that insulin has 1.5-fold higher affinity and a 2-fold higher dissociation rate for IR-A, than for IR-B [16]. On the other hand, IR-B binds insulin with higher affinity than for insulin like growth factor II (IGF-II) [3]. Additionally, it has been recently shown that IR-A binds IGF-II with a lower affinity than insulin [17], in contrast with a previous report informing similar affinities [3]. Over-expression of IR-A was suggested to contribute to the modulation of insulin and IGF responses in different tissues and during cancer progression [18]. Hybrid receptors are formed in cells where IR and IGF-I receptor (IGF-IR) are coexpressed and this is common in tumor tissues. Thus, the relative expression levels of IR-A, IR-B and IGF-IR affect sensitivity to ligands (IGF-I, IGF-II, insulin).

The link between metabolic and mitogenic effects of insulin are clinically relevant since, for instance, insulin treated type 2 diabetics are more likely to develop tumors [19]. Furthermore, their cancer risk may be modified by different treatments $[20,21]$ and modified insulin analogues with distinct receptor-binding characteristics showed different mitogenic potencies in cell lines and

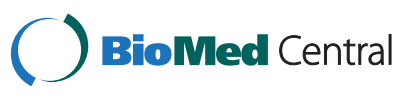

(C) 2013 Giudice et al.; licensee BioMed Central Ltd. This is an Open Access article distributed under the terms of the Creative Commons Attribution License (http://creativecommons.org/licenses/by/2.0), which permits unrestricted use, distribution, and reproduction in any medium, provided the original work is properly cited. 
animals [22,23]. Increase in mitogenicity was observed in analogues with lower dissociation constant from the IR [24].

Binding of insulin to the IR leads to its kinase activation, promoting the phosphorylation in cis and trans of tyrosine residues. Phosphorylated IR activates downstream cascades affecting glucose uptake, metabolism, cell growth, differentiation, gene expression and cell cycle progression. It has been postulated that the balance between these effects is affected by the receptor localization and redistribution. Activated ligand-receptor complexes are internalized into endosomes where the IR kinase would be able to phosphorylate substrates that are spatially distinct from those accessible at the plasma membrane affecting the balance between metabolic and mitogenic response. At the cell membrane activated IR recruits IRS-1 and Akt leading to the translocation of the glucose transporter and the activation of the metabolic response [25]. On the other hand, endosomes have long been proposed as signaling platforms [26], and activated IR internalization is required for the activation of the Shc/MAPK leading to the activation of early response genes and the activation of the activating protein transcription factors (AP-1), a hallmark of the mitogenic response [27-29].

Here we describe an IR-B chimera that can be modified exclusively at the plasma membrane by inserting three copies in tandem of the A1 tag [30] in the second Fibronectin type III domain (FnIII-2) of IR-B. This chimera binds insulin but fails to be activated or internalized. We show that it acts as a selective dominant negative IR by retaining the activated receptor at the plasma membrane, blocking AP-1 induction but maintaining Akt activation.

\section{Results and discussion}

Recently we studied insulin and IGF-II endocytosis dynamics in living cells through IR-B [31,32]. Here we report novel IR-B chimeras containing an extracellular tag suitable to be covalently modified at the plasma membrane. The tag, cloned into the IR-B sequence, is specifically recognized by the acyl carrier protein (ACP) syntase (ACP-S) which transfers a 4'-phosphopantetheine group from the Coenzyme A (CoA) to a conserved serine inside the A1 sequence. This approach allowed us to label IR-B with small fluorescent dyes or biotin exclusively at the plasma membrane and the modification showed no effect on insulin binding. These chimeras bind insulin but fail to be activated being retained at the cell surface. Co-expression with wild type IR showed that these mutants function as selective dominant negatives inhibiting the induction of AP-1 activity by insulin without affecting Akt activation.

\section{Imaging of IR exclusively at the plasma membrane}

We generated the plasmids pcDNA3-IR-B-A1 $\times 3$ (Mut) and pcDNA3-IR-B-A1 $\times 3-$ GFP (Mut-GFP) by fusing the
A1 tag (GDSLDMLEWSLM) [30] three times in tandem into the IR-B at the position 626 of the amino acids sequence (exon 9). This position is localized on the FnIII-2 domain of IR-B (Figure 1A), and does not contain known residues involved in pathological mutations, glycosilations sites, or cysteines which are important in post-transductional modifications. We hypothesize that this position does not affect insulin binding since it is located inside a domain that is not involved in the ligandreceptor ligand contact $[33,34]$. Other chimeras tagged on the first large Leucine rich domain (L1) showed correct expression but failed to bind insulin (unpublished data). The new chimeras allowed us to label the IR extracellular portion in living cells following the protocol showed in Figure 1B. Cells expressing the tagged IR mutants were labeled using ACP-S which transfers a 4'phosphopantetheine group from the CoA to the A1 sequence (in red, Figure 1A). When the membrane impermeable $\mathrm{CoA}$ is covalently bound to a fluorescent or a biotinylated group by the sulfhydryl extreme this modification is transferred to the tagged protein exposed to the extracellular medium.

Living HeLa cells expressing the chimeras (Figure 1C-E) were labeled with $0.2 \mu \mathrm{M} \mathrm{ACP-S}$ and $1 \mu \mathrm{M}$ CoA conjugated with the fluorescent ATTO-532 (CoA-532) or CoA-550. Both mutants localize correctly at the plasma membrane. Co-localization between green fluorescent protein (GFP) and CoA-550 signals was evaluated by Manders analysis: CoA-550 associated pixels were localized to the plasma membrane and co-localized with GFP signal (Figure 1E). Western blot experiments showed the correct molecular weight and similar levels of expression than wild type IR-B (Figure 1F). It should be noted that expression levels of endogenous IR in HeLa cells are bellow the detection threshold of our experimental approach as we have previously reported [32].

\section{Tagged IR-B binds insulin but fails to be activated}

Next, we studied the ability of the tagged receptors to bind insulin. Cells were incubated with $50 \mathrm{nM}$ biotin amido caproyl insulin (BAC-Ins) for $15 \mathrm{~min}$ and then with $1 \mathrm{nM}$ streptavidin (SA) conjugated quantum dots (QD) 655 (QD655) (maximum emission pick: $655 \mathrm{~nm}$ ) for $10 \mathrm{~min}$ at room temperature [30]. QD incubation was performed with or without previous ACP labeling (Figure 2). Cells expressing Mut-GFP showed insulin binding with or without ACP labeling (Figure 2A-D). Similarly, insulin binding was observed in cells expressing Mut previously labeled with CoA-488 (Figure 2E). Binding have shown to be specific since non-transfected cells did not show QD655 signal (non-transfected cells at the same observation field and data not shown).

Activation of the tagged IR in response to insulin was analyzed by immunofluorescence using a specific 

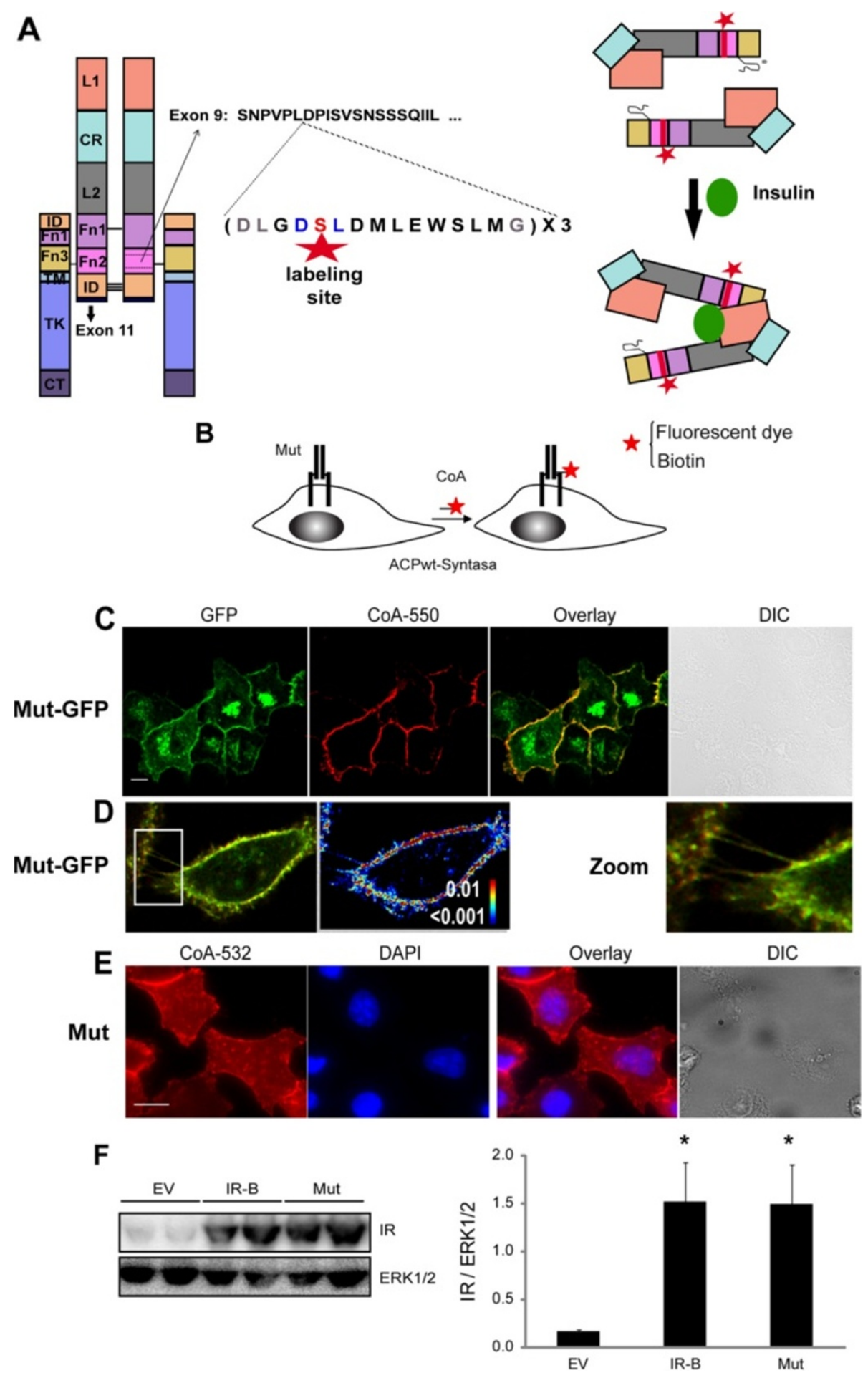

Figure 1 Covalent modification of IR-B at the plasma membrane. A. Tag position and insulin binding scheme according to proposed model [33,34]. L1, Large leucine rich domain 1; CR, cysteine rich domain; L2, large leucine rich domain 2; Fnlll domains 1, 2 and 3; ID, inter-domain; TM, transmembrane domain; TK, tyrosine kinase; CT, C-terminus. Inserted tag shows: in grey, residues added for cloning reasons; in red, Ser recognized by ACP-S; in blue, conserved flanking amino acids for enzyme recognition [30]. B. Labeling strategy. C-E. HeLa cells expressing MutGFP (C-D) or Mut (E) were labeled with $0.2 \mu \mathrm{M}$ ACP-S and $1 \mu \mathrm{M}$ fluorescent CoA and imaged by confocal (Mut-GFP) or wide field microscopy (Mut). Scale bars: $10 \mu \mathrm{m}$. D. Manders map. F. Cells transiently expressing wild type IR-B or the mutant were assayed by Western blot $48 \mathrm{~h}$ after transfection using anti-IR- $\beta$-subunit or anti-ERK1/2. Quantification was performed by densitometry. Results are expressed as the mean \pm s.e.m. (*: $p \leq 0.05 ; n \geq 3$ ). 


\section{A Insulin binding without ACP labeling}

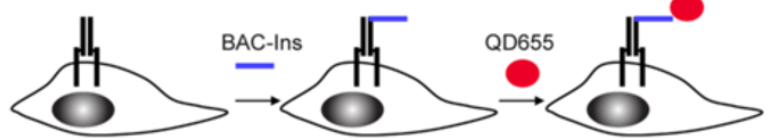

B

GFP QD655

DIC Overlay

Mut-GFP
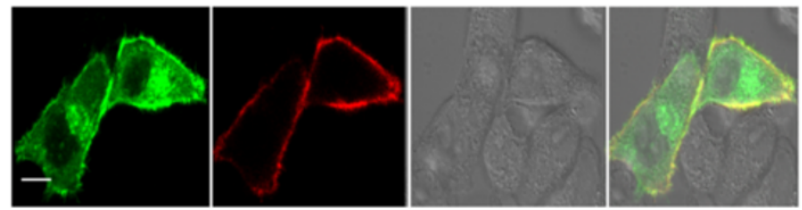

C Insulin binding after ACP labeling

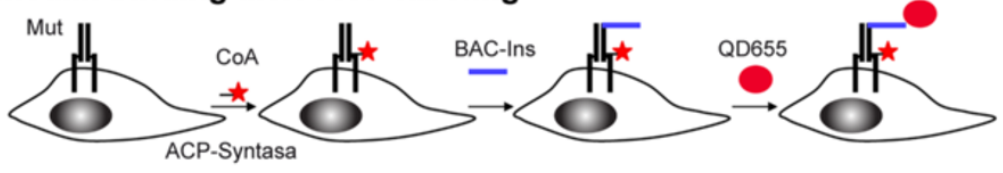

D Mut-GFP

GFP

CoA-532

QD655

Overlay
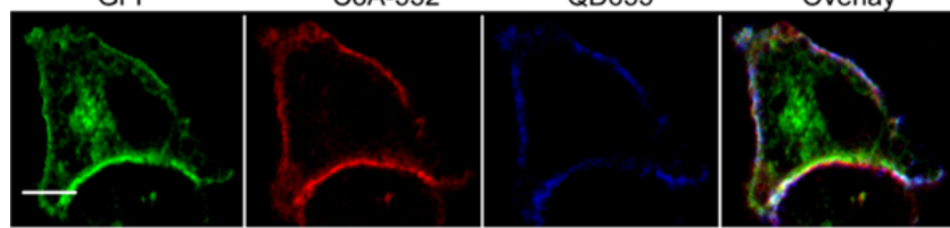

DIC

\section{E Mut}

CoA-488

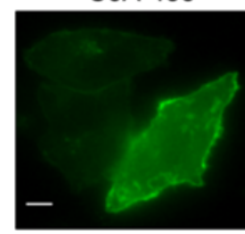

QD655

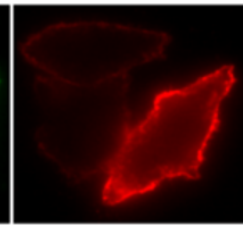

DAPI

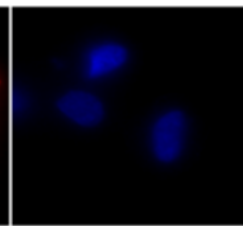

Overlay

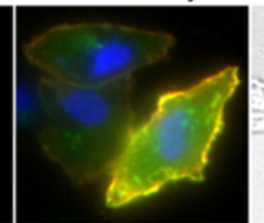

Figure 2 Insulin binding assays. A. Strategy for insulin binding and QD655 labeling. B. HeLa cells expressing Mut-GFP were incubated with 50 nM BAC-Ins and $1 \mathrm{nM}$ QD655, fixed and imaged by confocal microscopy. C. Insulin binging after ACP labeling. D-E. Cells expressing the mutants were labeled with $0.2 \mu \mathrm{M}$ ACP-S and $1 \mu \mathrm{M}$ fluorescent CoA and then with $50 \mathrm{nM}$ BAC-Ins and $1 \mathrm{nM}$ QD655. Imaging was performed by confocal (D) or wide field microscopy (E). Scale bars: $10 \mu \mathrm{m}$.

anti-phospho-IR- $\beta$ subunit (Tyr1361) antibody and by Western blot using an anti-phospho-tyrosine (pY20) antibody. While IR-B and IR-B fused to the super cyan fluorescent protein (SCFP) (IR-B-SCFP) could be activated after $10 \mathrm{~min}$ by recombinant human insulin (rhIns), both mutants did not show any activation signal (Figure 3). Activation in cells transfected with IR-B or IR-B-VFP was detectable by immunofluorescence and Western blot. By contrast, non-transfected cells (see cells without GFP signal in Figure 3C) or cells transfected with the empty vector [31] did not show detectable levels of activation. Activation of Mut-GFP was also analyzed after 5 or 15 min of rhIns stimulation and no activation was detected (Additional file 1: Figure S1).

Insulin binding leads to the phosphorylation of IR triggering different signaling pathways. However, IR signaling is not limited to its activation at the membrane. Activated ligand-receptor complexes are internalized into endosomes where the IR kinase would be able to phosphorylate substrates that are spatially distinct from those accessible at the plasma membrane. Therefore, we studied the endocytosis of the tagged IR after insulin binding ACP-S acts optimally at $37^{\circ} \mathrm{C}$ and at this condition receptors could be recycled or internalized. We tested two different labeling temperatures $\left(15^{\circ} \mathrm{C}\right.$ and room temperature) finding that room temperature allowed both ACP and QD labeling with undetected internalization (Additional file 2: Figure S2A). Cells expressing Mut were labeled at room temperature with BAC-Ins and QD655, incubated at $37^{\circ} \mathrm{C}$ and directly fixed or acid treated to remove the ligand bound to the IR at the cell surface [31,32,35]. After acid treatment no QD655 signal was detected inside the cells 


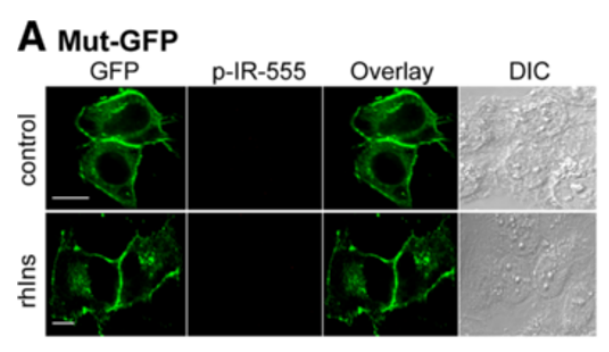

\section{B Mut}
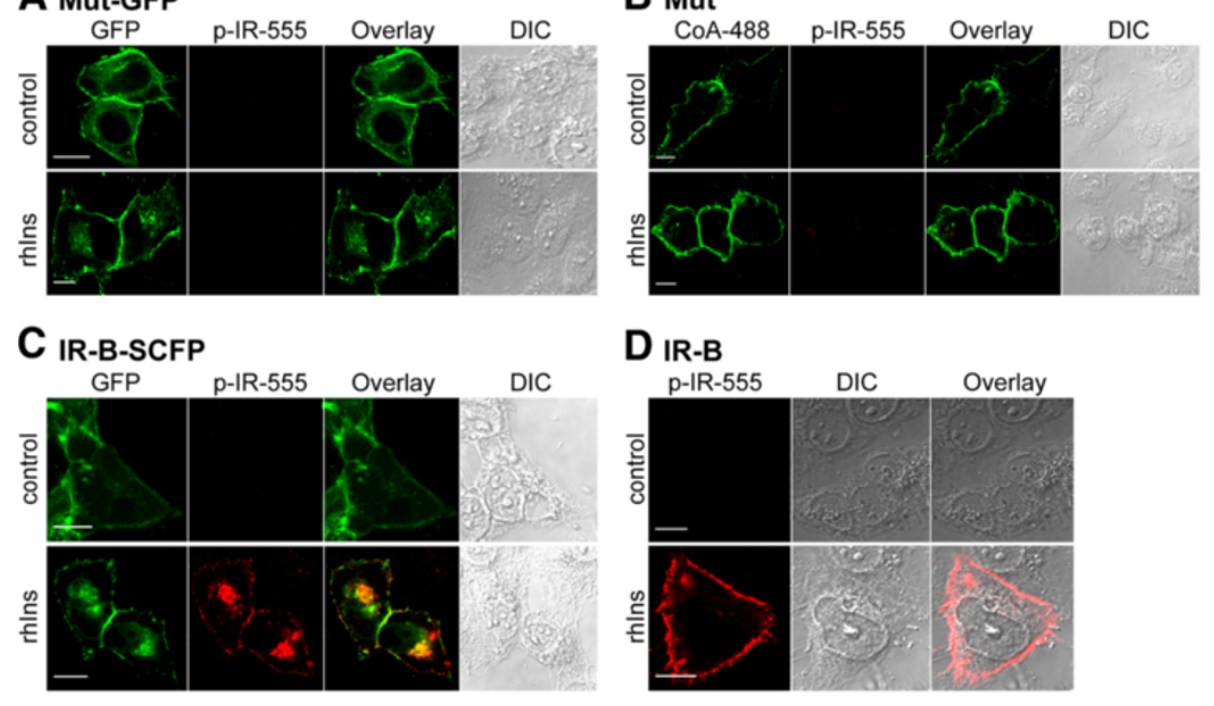

D IR-B
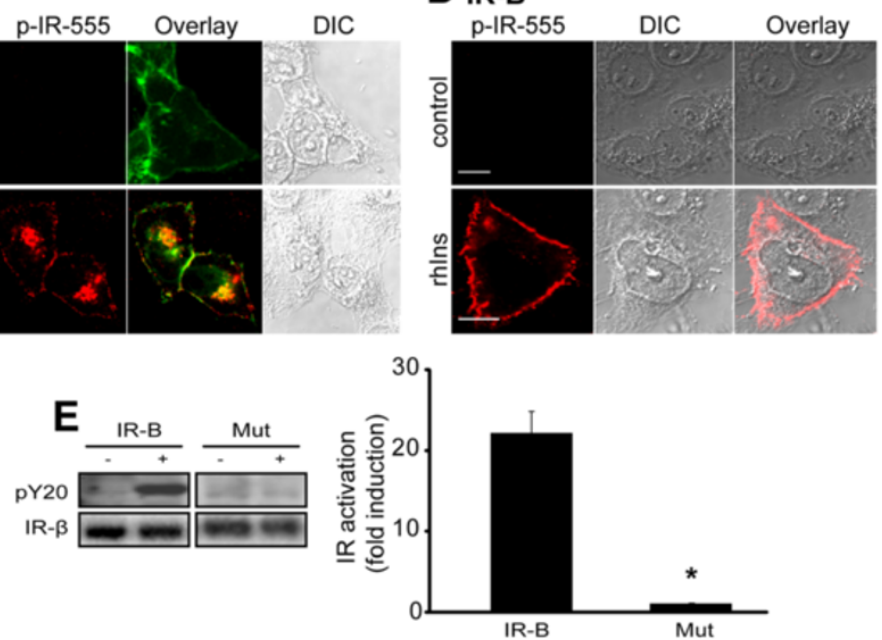

Figure 3 Chimeras characterization. A. HeLa cells expressing Mut-GFP (A), Mut (B), IR-B-SCFP (C) or IR-B (D) were stimulated with $100 \mathrm{nM}$ rhIns for $10 \mathrm{~min}$ and fixed. Immunofluorescence assays were performed with anti-phospho-IR and a secondary antibody conjugated with Alexa fluor 555. Cells expressing Mut were labeled with $0.2 \mu \mathrm{M}$ ACP-S and $1 \mu \mathrm{M}$ CoA-488 before stimulation. E. Cells expressing wt IR-B or the mutant were stimulated with $100 \mathrm{nM}$ rhlns for 5 min and lysates were analyzed by Western blot using anti-pY20 and anti-IR- $\beta$ subunit. Quantification was performed by densitometry. The ratio pY20 / IR was measured for each lane and fold induction was calculated with respect to basal levels. Results are expressed as the mean \pm s.e.m. (*: $p=0.002 ; n \geq 3$ ). ' $p$ ' means phospho-antibodies.

expressing the mutant (Figure 4A) suggesting that endocytosis was blocked. In contrast, cells expressing wt IR-B showed normal endocytosis (Figure 4B) [30].

\section{Mut dimerizes with functional IR at the plasma membrane and blocks its internalization}

We biotinylated the IR in cells co-expressing IR-B-SCFP and Mut and performed a SA-pull down assay followed by Western blot to confirm the presence of IR-B/Mut dimers at the plasma membrane. Transfected cells were incubated with $2 \mu \mathrm{M}$ ACP-S and $1 \mu \mathrm{M}$ CoA-biotin and correct surface modification was observed by labeling cells with $1 \mathrm{nM}$ SA-550. The modification was specific and only present at the surface (Additional file 2: Figure S2B). The presence of IR-B-SCFP in the pull down fraction indicates that Mut was able to dimerize with wild type receptors (Figure 5A). Densitometric and statistical analysis showed that dimerization occurred stochastically without differences between mutant or wild type receptors (Additional file 3: Supplemental Experimental Procedures).
To analyze Mut's effect on insulin signaling we first evaluated IR phosphorylation in cells co-expressing IR-B and increasing amounts of Mut. Western blot experiments showed that IR phosphorylation was reduced by Mut in a concentration dependent manner (Figure 5B) suggesting a dominant negative effect.

Cells co-expressing Mut and wild type IR-B showed that Mut blocks insulin-IR complex endocytosis (Figure 5C). Cells with high levels of mutant expression (revealed by CoA-488 signal) showed a low proportion of internalized BAC-Ins-QD655 compared with cells with a low expression where a high endocytosis degree was observed. We quantified the QD655 signal inside the cell, at the membrane and the percentage of internalized QD (Additional file 4: Figure S3). The mutant's effect on internalization was analyzed in cells co-expressing IR-B with similar expression levels (CoA-488>1600 cts). While IR-B is internalized ( $49 \pm 5 \% ; n=14)$, the mutant does not $(7 \pm 2 \% ; n=6)$ and retained IR-B at the membrane $(18 \pm 2 \% ; n=32)$ when they are co-expressed (Figure 5D). We further confirmed that no internalization took place at later time points $(15$, 


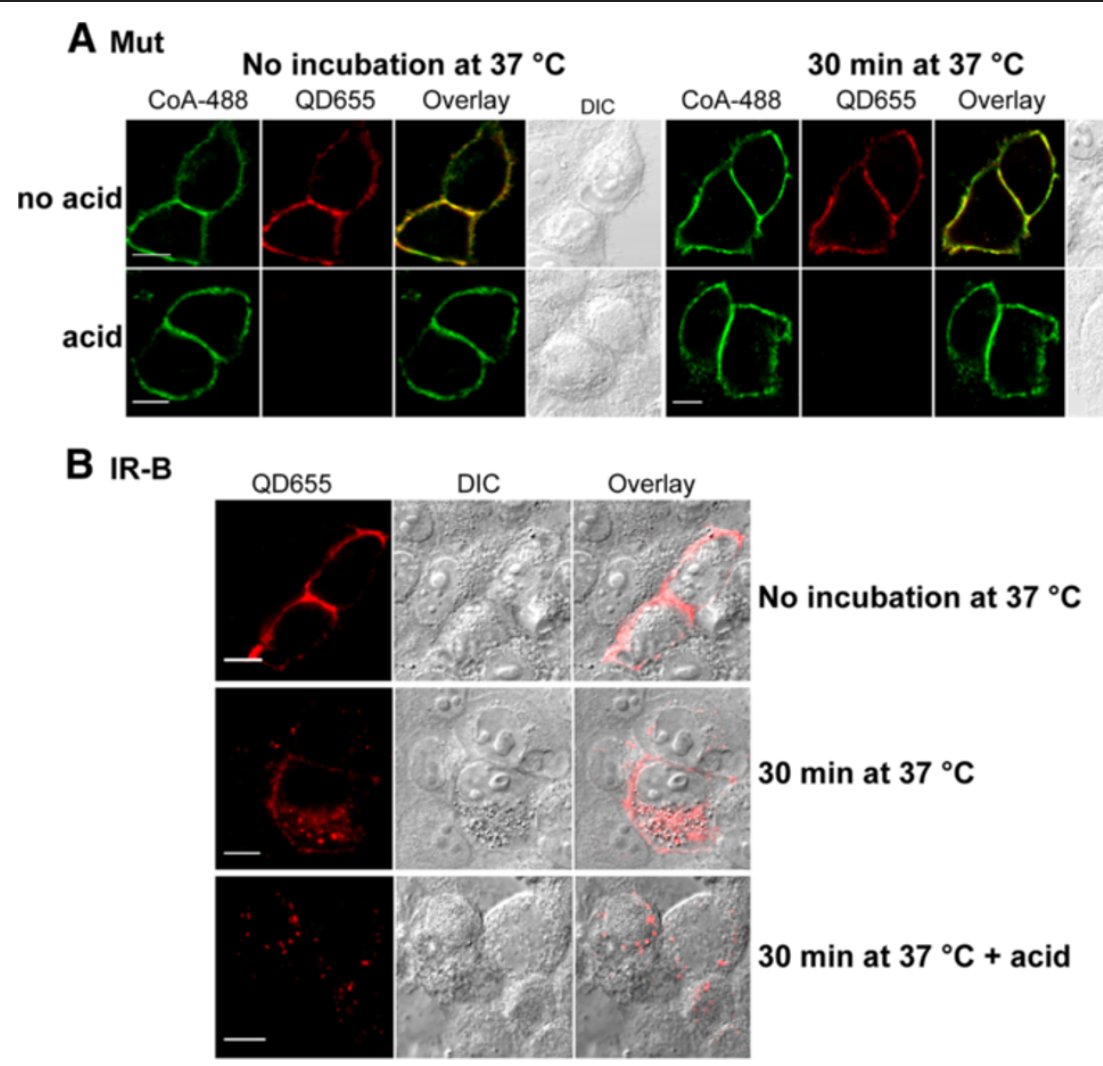

Figure 4 Mutant retention at the plasma membrane. A. HeLa cells expressing Mut labeled with $0.2 \mu \mathrm{M}$ ACP-S and $1 \mu \mathrm{M}$ CoA-488 were incubated with $50 \mathrm{nM} \mathrm{BAC-Ins}$ and $1 \mathrm{nM}$ QD655. Cells were fixed or acid treated before fixation. Right panel: cells were incubated at $37^{\circ} \mathrm{C}$ for 30 min and fixed with or without acid treatment. B. Cells expressing IR-B were labeled with 50 nM BAC-Ins and 1 nM QD655, incubated or not at $37^{\circ} \mathrm{C}$ for $30 \mathrm{~min}$ and fixed or previously acid treated. Samples were imaged by confocal microscopy. Scale bars: $10 \mu \mathrm{m}$.

45 and $150 \mathrm{~min}$ ) (Additional file 5: Figure S4). By contrast IR-B and IR-B-VFP showed almost complete insulin internalization after $150 \mathrm{~min}$ [31,32].

The IR phosphorylation pattern regulates its internalization and is the proposed mechanism for the divergence of the mitogenic and metabolic signaling. It was postulated that its kinase activity modulation leads to the differential balance between metabolic and mitogenic response [36].

\section{Mut blocks insulin induced AP-1 activity without affecting} Akt activation

To test the effect of the membrane retention downstream the IR, we measured AP-1 transcriptional activity induced by insulin using a luciferase reporter assay. Cells co-expressing AP-1-Luc, IR-B and increasing amounts of Mut were stimulated with $100 \mathrm{nM}$ rhIns for $16 \mathrm{~h}$. AP1 induction was significantly decreased by Mut in a concentration dependent manner (Figure 6A). To further analyze this effect on endogenous IR, we measured AP-1 activity in response to insulin in HEK293 cells, which express predominantly IR-A. Increasing amounts of Mut significantly reduced insulin induction of AP-1 activity (0.1 $\mu \mathrm{g}$ DNA: $44 \%$ of reduction; $0.2 \mu \mathrm{g}$ DNA: $92 \%$ of reduction) (Figure 6A). These results indicate that Mut-IR acts as a dominant negative in the pathway leading to AP-1 activation.

It is known that Akt translocates to the plasma membrane where interacts with the kinases that induce its activation to regulate glucose metabolism, differentiation, protein synthesis and cell survival and proliferation [37-39]. We confirmed Akt recruitment to the membrane after insulin activation by quantitative immunofluorescence. Cells co-expressing IR-B-SCFP and Akt-HA (Akt fused to the human influenza hemagglutinin tag, HA) were stimulated with rhIns and the proportion of Akt at the membrane was quantified. As expected, Akt translocated to the plasma membrane in response to insulin (control: $90 \pm 0.5 \%$; rhIns: $160 \pm 0.9 \% ; n=34-40$ cells; $p<10^{-5}$ ) (Figure 6B). Expression of the mutant alone or together with IR-B-SCFP did not change the intracellular redistribution of Akt after insulin stimulation (Figure 6C). Moreover, Western blot experiments showed that expression of the mutant increased Akt activation in a 

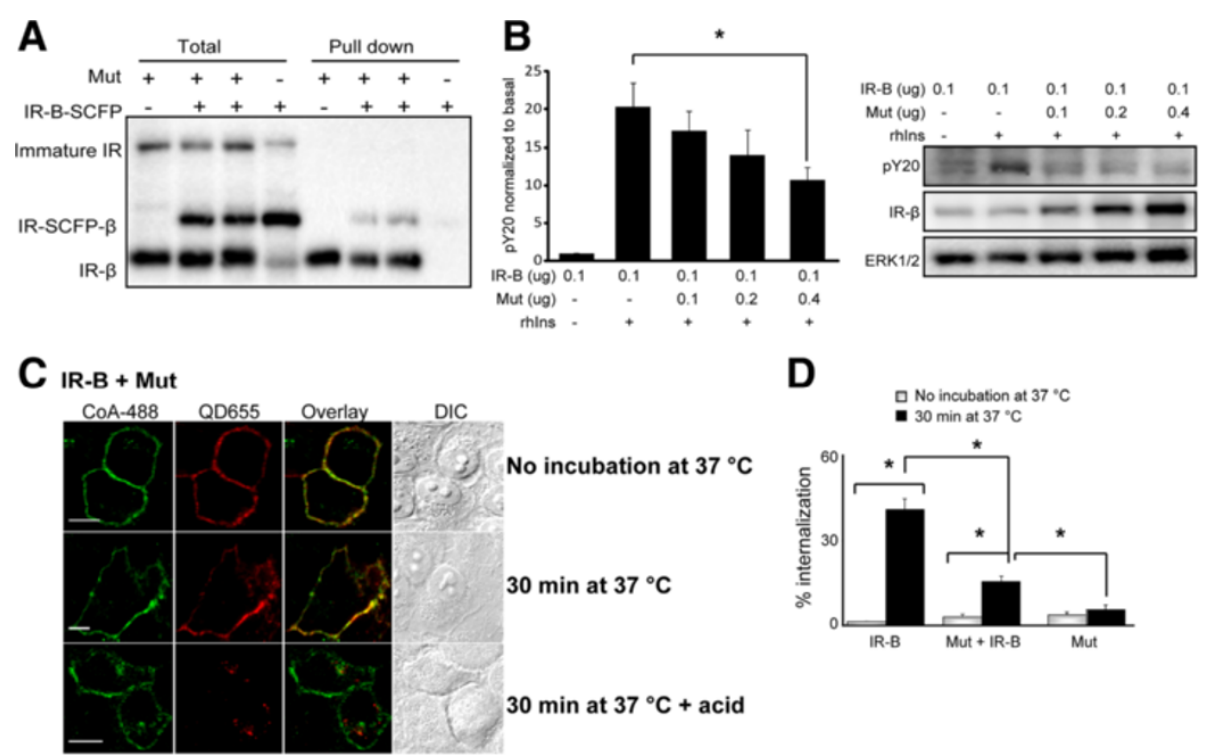

\begin{abstract}
Figure 5 Dimers wild type / mutant at the plasma membrane and signaling. A. HeLa cells expressing Mut, IR-B-SCFP or both were treated with $2 \mu \mathrm{M}$ ACP-S and $5 \mu \mathrm{M}$ CoA-biotin for $30 \mathrm{~min}$. Lysates were incubated with SA-agarose beads for $1 \mathrm{~h}$ at $4^{\circ} \mathrm{C}$. Precipitates and total fractions were analyzed by Western blot with anti-IR- $\beta$ subunit. B. HeLa cells were co-transfected with $0.1 \mu \mathrm{g}$ PCDNA3-IR-B and different amounts of the mutant or EV, stimulated with $100 \mathrm{nM}$ rhlns for $5 \mathrm{~min}$ and assayed by Western blot. Quantification was performed by densitometry measuring pY20 signal with respect to the first lane (basal) (*: $p<0.05, n=4)$. C. HeLa cells co-expressing Mut and IR-B were labeled with $2 \mu \mathrm{M}$ ACP-S and 2 $\mu \mathrm{M}$ CoA-488 and then incubated with $50 \mathrm{nM} \mathrm{BAC-Ins}$ and $1 \mathrm{nM}$ QD655. Cells were directly fixed or incubated for 30 min at $37^{\circ} \mathrm{C}$ and then fixed or acid treated before fixation. Samples were imaged by confocal microscopy. Scale bars: $10 \mu \mathrm{m}$. D. Internalization analysis. Results are expressed as the mean \pm s.e.m $(p<0.005 ; n=6-32$ cells).
\end{abstract}

concentration dependent manner (Figure 6D). This effect is not observed for ERK1/2 activation (Additional file 6: Figure S5).

There are at least seven tyrosines subjected to phosphorylation upon insulin binding [40]: Tyr965 and Tyr972 are phosphorylated in cis and involved in substrates selection [41]; Tyr1328 and Tyr1334 play a key role in mitogenic signaling and are not involved in metabolism and Akt signaling [42,43]; Tyr1158, Tyr1162 and Tyr1163 are the first residues to be phosphorylated in trans, known to mediate kinase activation and internalization [44]. It has been postulated that the degree of IR kinase activation leads to the differential balance between metabolic and mitogenic response [36]. IR internalization is required for Shc/MAPK pathway activation but not for IRS-1 and Akt phosphorylation suggesting that these molecules could be activated at the membrane [37-39,45-47]. We hypothesize that the mutant, acting both in cis or trans, could be affecting the phosphorylation pattern of the hertero- and homo-dimers blocking IR internalization and favoring membrane signaling.

\section{Conclusions}

These results suggest that the mutant is acting as a selective dominant negative, blocking internalization and signaling from endosomes without affecting Akt activation at the cell surface. Our results are in agreement with the model proposing that the internalization dynamics is crucial for specific IR signaling suggested from different independent studies and reviewed by Jensen and De Meyts [47]. The mutant binds insulin but fails to get activated. When this chimera dimerizes with wild type IR, hybrid receptors fail to get fully phosphorylated and are consequently retained at the plasma membrane, promoting Akt activation and inhibiting endosomal signaling.

\section{Methods}

\section{Materials}

rhIns was provided by Laboratorios Beta (Argentina). BAC-Ins was from Sigma (Germany). Mouse monoclonal anti-IR- $\beta$ subunit, rabbit monoclonal anti-phospho-Akt (Ser473), anti-Akt, anti-ERK1/2 and anti-phospho-IR- $\beta$ subunit (Tyr1361) were from Cell Signaling Technology (Beverly, MA). Mouse monoclonal anti- pY20 was from BD Transduction Laboratories (San Jose, CA). Mouse monoclonal anti-PY99 was from Santa Cruz Biotechnology (Santa Cruz, CA). QD655 and secondary antibodies conjugated with Alexa fluor 555 were from Molecular Probes, Invitrogen (Eugene, OR). Lipofectamine Reagent 2000 was from Invitrogen (Carlsbad, CA). Buffers and enzymes for cloning were from New England Biolabs (Ipswich, UK), Promega (Madison, WI) and Invitrogen 

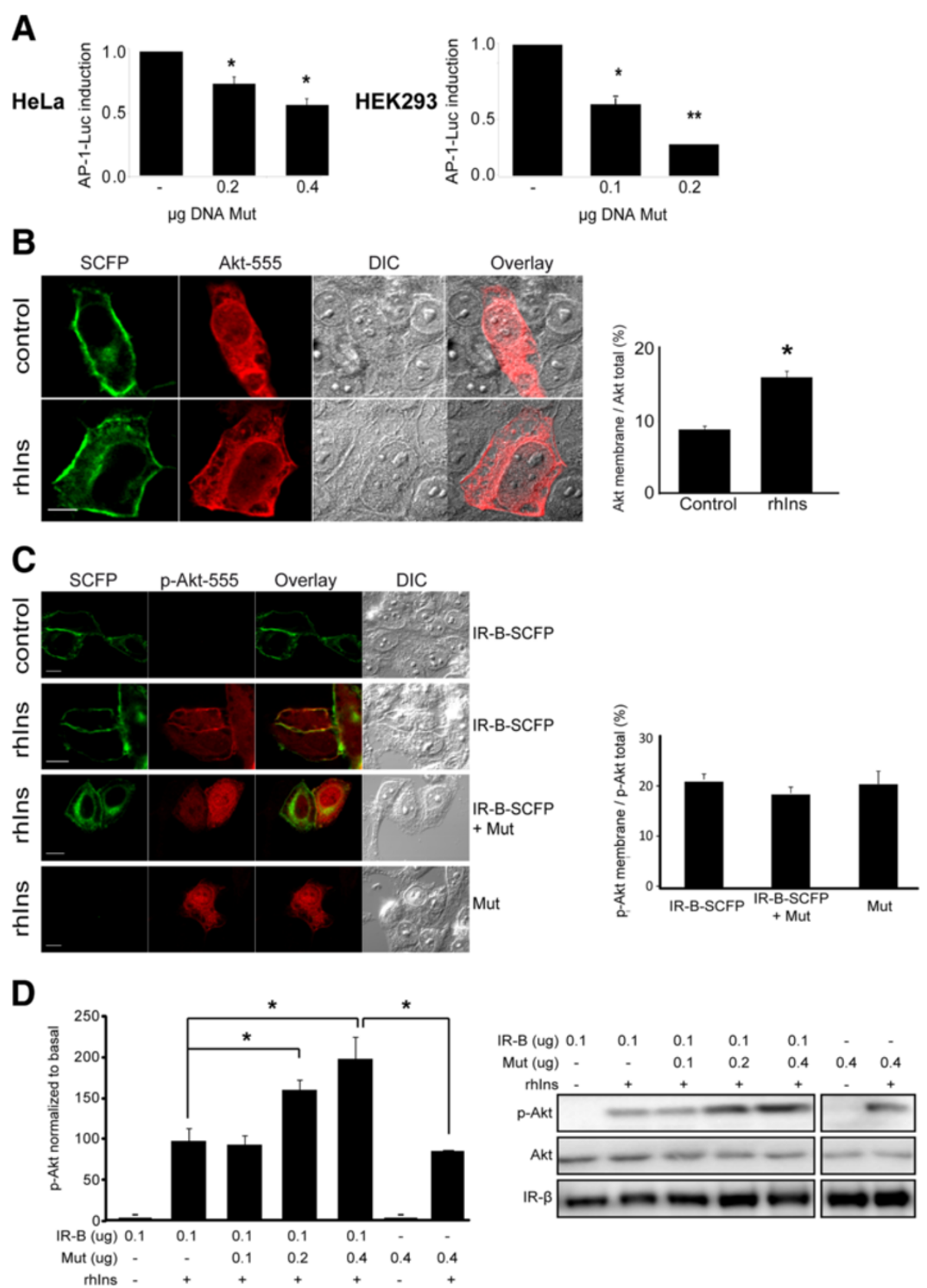

Figure 6 Mutant IR blocks insulin induced AP-1 activity without affecting Akt activation. A. HeLa or HEK293 cells co-expressing AP1-LuC, IR-B and different amounts of the mutant were starved for $24 \mathrm{~h}$ and then stimulated with $100 \mathrm{nM}$ rhlns for $16 \mathrm{~h}$. Luciferase activity was measured and fold induction was calculated (*: $p \leq 0.03,{ }^{* *}: p=0.003 ; n \geq 3$ ). B. Akt translocation to the plasma membrane: HeLa cells co-expressing IR-B-SCFP and Akt-HA were starved overnight and then stimulated with $100 \mathrm{nM}$ rhlns for $5 \mathrm{~min}$. After fixation samples were stained with anti-Akt and a secondary antibody conjugated with Alexa fluor 555. Images were acquired by confocal microscopy and quantification of Akt re-distribution was evidenced (*: $p<10^{-6} ; n=34-40$ cells). Scale bars: $10 \mu \mathrm{m}$. C. Similar experiment was performed using anti-phospho-Akt in cells co-expressing Akt-HA with: i) IR-B-SCFP, ii) Mut iii) both ( $n=15-23$ cells). D. Cells co-transfected with $0.1 \mu \mathrm{g}$ pcDNA3-IR-B and different amounts of the mutant or EV were stimulated with $100 \mathrm{nM}$ rhlns for 5 min and assayed by Western blot. Quantification was performed by densitometry measuring phospho-Akt signal normalized to the first lane (basal) (*: $p<0.05, n \geq 3$ ). ' $p$ ' means phospho-antibodies. Results are expressed as the mean \pm s.e.m.

(Carlsbad, CA). Ni-NTA resin was from QIAGEN (Valencia, CA). The plasmid containing luciferase reporter gene downstream of 7 binding sites for AP-1 (p-AP-1-Luc) and Akt-HA were generously provided by Dr Omar Coso and Dr Anabella Srebrow (IFIBYNE, Argentina) respectively. The plasmids pcDNA3-IR-B, pcDNA3-IR-B-GFP and pcDNA3-IR-B-SCFP were recently described $[31,32]$. 


\section{Generation of expression constructs}

$p c D N A 3-I R-B-A 1 \times 3-G F P$ (Mut-GFP): oligonucleotides with the A1 sequence (A1BamHI5': 5'-gatcttggtgactctctgg acatgctggagtggagtctgatgggt-3'; A1BamHI3': 5' -gatcacccatc agactccactccagcatgtccagagagtcaccaa- $3^{\prime}$ ) were annealed for $5 \mathrm{~min}$ at $100^{\circ} \mathrm{C}$ cooling it to $\mathrm{RT}(500 \mathrm{mM} \mathrm{NaCl}, 10 \mathrm{mM}$ EDTA, $100 \mathrm{mM}$ Tris- $\mathrm{HCl} \mathrm{pH}$ 7.5). Presence of double strand DNA with sticky ends for BamHI was tested by an absorption spectrum. Annealing product was treated with T4 PNK. The pcDNA3-IR-B-GFP was digested with $B a m H I$ restriction enzyme and ligated with the A1 tag with the $B a m H I$ ends. $p c D N A 3-I R-B-A 1 \times 3$ (Mut): MutGFP was digested with $N h e \mathrm{I}$ and $A p a \mathrm{I}$ restriction enzymes, treated with Klenow and T4 DNA polymerase and then re-ligated to generate Mut.

\section{Cell culture and transfections}

HeLa cells were maintained in DMEN (GIBCO; Grand Island, NE) supplemented with $100 \mathrm{U} / \mathrm{ml}$ penicillin, $100 \mu \mathrm{g} / \mathrm{ml}$ streptomycin and $10 \%$ fetal bovine serum (FBS) at $37^{\circ} \mathrm{C}$ in $5 \% \mathrm{CO}_{2}$. HEK293 cells were similarly maintained adding $1 \mathrm{mM}$ sodium pyruvate. Cells were plated at $1 \times 10^{5}$ cells/well density in 24 well plates (luciferase assays) or onto $12 \mathrm{~mm}$ glass coverslips (microscopy) or at $2.5 \times 10^{5}$ cells/well density in 12 wells plates (Western blot) one day before transfection in DMEM/10\% FBS. Cells were transfected with Lipofectamine Reagent 2000 according to manufacturer protocols.

\section{Western blots}

Following stimulation with $100 \mathrm{nM}$ rhIns cells were lysed in $100 \mathrm{mM}$ Tris- $\mathrm{HCl} \mathrm{pH}$ 6.8, 4\% SDS, 0.2\% Bromophenol blue, $20 \%$ glycerol, $200 \mathrm{mM} \beta$-mercaptoethanol, vortexed for $20 \mathrm{sec}$ and boiled for $5 \mathrm{~min}$. After 10\% SDS-PAGE and transfer, PDVF membranes were blocked in 5\% non-fat dried milk in $0.1 \%$ Tween-TBS buffer (TTBS) for $1 \mathrm{~h}$, washed and incubated overnight at $4{ }^{\circ} \mathrm{C}$ with primary antibodies diluted in 5\% BSA/TTBS. The following day, membranes were incubated with secondary antibodies for $1 \mathrm{~h}$ and developed by chemiluminescence. Quantification was performed by densitometry using ImageJ plugins (NIH).

\section{Luciferase reporter assay}

Cells seeded onto 24 well plates the day before were transfected using $0.3 \mu \mathrm{g}$ pcDNA3-IR-B (HeLa cells) or EV (HEK293 cells), $0.05 \mu \mathrm{g}$ pAP-1-Luc and different amounts of Mut. After $24 \mathrm{~h}$, cells were starved one day, and then stimulated for $16 \mathrm{~h}$ with $100 \mathrm{nM}$ rhIns. Luciferase activity was determined using Luciferase Reactive and Reporter Lysis Buffer from Promega (Madison, WI) and normalization to the control (non-stimulated cells) was performed.

\section{Expression and purification of ACP-S Protein expression}

TOP 10 Ecoli cells (araBADC- and araEFGH+) were electroporated with pBAD-ACPwt-S plasmid (provided by T.M. Jovin and D.J. Arndt-Jovin, Max Planck Institute for Biophysical Chemistry, Germany), plated on Luria Broth agar and incubated at $37^{\circ} \mathrm{C}$ overnight. The next day, a $2 \times$ YT starting culture was inoculated overnight at $37^{\circ} \mathrm{C}$. We diluted $(1 / 200)$ the starting culture and growth it at $37^{\circ} \mathrm{C}$ to an optical density of 0.8 . The expression was induced with $0.1 \%(\mathrm{w} / \mathrm{v}) \mathrm{L}-(+)$-arabinose (SIGMAAldrich, Germany)and incubation at $30^{\circ} \mathrm{C}$ overnight and the next day cells were harvested. The pellet was resuspended $(10 \mathrm{ml} / \mathrm{g}$ pellet) in Lysis Buffer $(80 \mathrm{mM}$ imidazole $\mathrm{pH}$ 8.0, $250 \mathrm{mM} \mathrm{NaCl}$ and protease inhibitor) and was sonicated $3 \times 15 \mathrm{sec}$. Then $1 \%$ Triton X-100 was added and the suspension was stirred for $15 \mathrm{~min}$ at $4^{\circ} \mathrm{C}$. Lysates were centrifuged at 9,500 r.p.m. for $30 \mathrm{~min}$ at $4^{\circ} \mathrm{C}$ collecting the supernatant.

\section{Protein purification by Ni-NTA chromatography}

The cleared lysate was incubated with Ni-NTA resin (20 ml resin per $500 \mathrm{ml}$ lysate) at $4{ }^{\circ} \mathrm{C}$ for $1 \mathrm{~h}$ with stirring. The resin was then loaded in a $10 \mathrm{ml}$ syringe, washed with Wash Buffer 1 (500 mM NaCl, $100 \mathrm{mM}$ imidazole pH 8.0) and then with Wash Buffer $2(100 \mathrm{mM} \mathrm{NaCl}, 100 \mathrm{mM}$ imidazole $\mathrm{pH}$ 8.0, $20 \%$ glycerol). Elution was performed with $100 \mathrm{mM} \mathrm{NaCl}, 400 \mathrm{mM}$ imidazole $\mathrm{pH} 8.0,20 \%$ glycerol. Fractions were analyzed by SDS-PAGE and by measuring absorption at $280 \mathrm{~nm}$. Fractions containing the protein were combined and stored at $-80^{\circ} \mathrm{C}$ with $1 \mathrm{mM}$ DTT after shock-freezing in liquid nitrogen.

\section{CoA derivatives synthesis CoA-biotin}

CoA trilithium salt (FLUKA, St Louis, MO) (1 equivalent) was dissolved in $50 \mathrm{mM}$ Tris- $\mathrm{HCl} \mathrm{pH} 7.5$ by adding 10 volumes of dimethyl sulfoxide (DMSO). This solution was combined with Biotin- $\mathrm{PeO}_{2}$-maleimide (Pierce, Rockford, IL) (1 equivalent) dissolved in DMSO at room temperature for $4 \mathrm{~h}$. Product reaction was purified by Fast protein liquid chromatography (ÄKTA Purifier 100, GE Healthcare Life Science) with a reverse phase column C18 Kromasil MZ refill $100(150 \mathrm{~mm} \times 4 \mathrm{~mm})$. Elution was performed with a gradient acetonitrile: water $/ 0.1 \%$ trifluoroacetic acid from 0:100 to 60:40 in $45 \mathrm{~min}$. The purified product was characterized by Matrix-Assisted Laser Desorption/Ionization using a time of flight ion detector (CEQUIBIEM, FCEN-UBA, Argentina) with matrix 3-hidroxipicolinic acid. Quantification was performed by spectrophotometry $\left(\varepsilon_{\text {adenine260nm }}=15,300 \quad \mathrm{M}^{-1} \mathrm{~cm}^{-1}\right)$. The product was lyophilised, resuspended in DMSO and stored at $-20^{\circ} \mathrm{C}$. 


\section{Fluorescent CoA}

ATTO-maleimide $(488,532$, 550) (ATTO Tec GmbH, Germany) (2 equivalents) was dissolved in DMSO and CoA trilithium salt (1 equivalent) was dissolved in MES (2-(N-morpholino) ethanesulfonic acid) buffer $\mathrm{pH} 7.0$ and one volume of DMSO. We combined both solutions at $20^{\circ} \mathrm{C}$ overnight. The product was purified by HPLC with a reverse phase column C18 Kromasil MZ semiprep $100(250 \mathrm{~mm} \times 8 \mathrm{~mm})$ and the following elution gradient: (i) $2 \mathrm{~min}$ ammonium acetate: acetonitrile (97:3); (ii) $20 \mathrm{~min}$ from 97:3 to 40:60; (iii) $5 \mathrm{~min}$ from 40:60 to 0:100. The product identity was confirmed by mass spectrometry, spectrophotometry and by labeling cells expressing A1 tag with ACP-S. Fluorescent CoA was lyophilized, resuspended in DMSO and stored at $-20^{\circ} \mathrm{C}$.

\section{Label in vivo with ACP-S and CoA derivatives}

Transfected cells were washed with Tyrode's buffer (135 mM NaCl, $10 \mathrm{mM} \mathrm{KCl,} 10 \mathrm{mM} \mathrm{MgCl}_{2}, 1 \mathrm{mM}$ $\mathrm{CaCl}_{2}, 10 \mathrm{mM}$ HEPES pH 7.2, 0.1\% BSA) and incubated with 0.2 or $2.0 \mu \mathrm{M}$ ACP-S and $1 \mu \mathrm{M}$ CoA derivatives for $30 \mathrm{~min}$ at room temperature and finally washed four times with Tyrode's CoA-biotin modification was followed by a labeling step with $1 \mathrm{nM}$ SAatto550 for $15 \mathrm{~min}$ at room temperature. Then cells were fixed in cold methanol for $30 \mathrm{~min}$ at $-20^{\circ} \mathrm{C}$ and mounted for imaging.

\section{Labeling in vivo with QD655 and BAC-Ins and internalization}

Before the experiment cells were starved overnight and then incubated with $50 \mathrm{nM}$ BAC-Ins for $15 \mathrm{~min}$ at room temperature, washed and incubated with $1 \mathrm{nM}$ QD655 for $10 \mathrm{~min}$, washed and either fixed in 37\% paraformaldehyde (PFA) on ice for $20 \mathrm{~min}$ or incubated at $37^{\circ} \mathrm{C}$ in DMEM for different periods before fixation. When acid treatment was applied, cells were incubated for $5 \mathrm{~min}$ at room temperature with acid solution (0.1 M Na-glycine $\mathrm{pH} 3.0,0.5 \mathrm{M} \mathrm{NaCl}$ ) [28-30] and then fixed Imaging was performed in PBS.

\section{Immunofluorescence}

After overnight starvation, transfected cells were stimulated with $100 \mathrm{nM}$ rhIns for 5, 10 or $15 \mathrm{~min}$, washed with cold PBS and immediately fixed in cold methanol for $30 \mathrm{~min}$ at $-20^{\circ} \mathrm{C}$, blocked with $\mathrm{PBS} / 0.3 \%$ Triton $\mathrm{X}-100$ / $1 \%$ BSA for $1 \mathrm{~h}$ at $37^{\circ} \mathrm{C}$ and incubated with anti-phosphoIR- $\beta$ subunit $(0.3 \mu \mathrm{g} / \mathrm{ml})$, anti-PY99 $(1 \mu \mathrm{g} / \mathrm{ml})$, anti-Akt $(1 / 400)$ or anti-phospho-Akt $(1 / 200)$ overnight at $4^{\circ} \mathrm{C}$. The following day samples were incubated with a secondary antibody conjugated with Alexa fluor 555 or Cy3 for $1 \mathrm{~h}$ at $37^{\circ} \mathrm{C}$, washed and mounted for imaging.

\section{Microscopy}

Confocal microscopes were Olympus Fluoview FV1000 with a UPLSAPO $60 \times 1.2$ N.A. water immersion objective or Zeiss LSM510 Meta with a C-Apochromat $63 \times 1.2$ N.A. water immersion objective or a Plan-Apochromat $63 \times 1.4$ N.A. oil immersion objective. Excitation and emission filters were as follows:

SCFP and Alexa fluor 555: Excitation: SCFP, $405 \mathrm{~nm}$; Alexa fluor 555, $543 \mathrm{~nm}$. Emission: SCFP, band-pass (BP): 430-470 nm; Alexa fluor 555, BP: 560-620 nm. CoA-488 and QD655: Excitation: CoA-488, $488 \mathrm{~nm}$; QD655, 405 nm. Emission: CoA-488, BP: 505-525 nm; QD655, BP: 640-670 nm.

GFP and Alexa fluor 555: Excitation: GFP, $488 \mathrm{~nm}$; Alexa fluor 555, $543 \mathrm{~nm}$. Emission: GFP, BP: 505-525 nm; Alexa fluor 555, BP: 560-620 nm.

CoA-488 and Alexa fluor 555: Excitation: CoA-488, $488 \mathrm{~nm}$; Alexa fluor 555, $543 \mathrm{~nm}$. Emission: CoA-488, BP: 505-525 nm; Alexa fluor 555, BP: 560-620 nm. GFP and CoA-532: Excitation: GFP, $488 \mathrm{~nm}$; CoA-532, $532 \mathrm{~nm}$. Emission: GFP, BP: 500/20 nm; CoA-532, 563-606 nm.

GFP, CoA-532 and QD655: Excitation: GFP, $488 \mathrm{~nm}$; CoA-532, 532 nm; QD655, 488 nm. Emission: GFP, BP: 500/20 nm; CoA-532, BP: 565-615 nm; QD655, longpass: $650 \mathrm{~nm}$.

Wide field microscope was Olympus IX71 with a 40× 1.15 N.A. water immersion objective, a mercury arc lamp excitation, suitable filters and a camera Hamamatsu Orca CCD C4742-95.

\section{Image processing}

Confocal images were processed with Matlab and ImageJ. Background was subtracted and in some cases a median filter was applied only for presentation.

\section{Internalization analysis}

\section{Segmentation (membrane-interior)}

Channel background (median) was subtracted. Cell segmentation was performed manually and pre-membrane was defined as the difference image of the cell and binary erosion (iterations: 5-20; alternating connectivity). The pre-interior was defined as the difference between cell and pre-membrane. With a mask marking red pixels (QD655) membrane was defined as the product mask $\times$ pre-membrane, and interior as the product mask $\times$ pre-interior.

\section{Endocytosis estimation}

Values in membrane and interior were summed for both channel, also sizes were measured In order to compute the relative amount of internalized red fluorescence we estimated $\mathrm{QD}_{\text {total }}\left(\mathrm{QD}_{\text {membrane }}+\mathrm{QD}_{\text {interior }}\right)$ and calculated 
the ratio $\mathrm{QD}_{\text {iinterior }} / \mathrm{QD}_{\text {total }}$ for each cell. Expression levels were estimated as the mean of the CoA-488 signal (sum of CoA-488/cell size). Cells with similar CoA-488 level were considered.

\section{Quantification of Akt distribution}

Each cell was segmentated similarly using SCFP signal, red signal was measured in each region and $\mathrm{Akt}_{\text {membrane }} /$ $\mathrm{Akt}_{\text {total }}$ ratio was calculated.

\section{Pull down experiments}

Cells expressing the mutant alone or in combination with IR-B-SCFP were growth on six well plates. Cells were incubated with $2 \mu \mathrm{M}$ ACP-S and $5 \mu \mathrm{M}$ CoA-biotin for $30 \mathrm{~min}$ at room temperature and after 4 washes with PBS were lysed (50 mM Tris- $\mathrm{HCl} \mathrm{pH} 7.5,1 \mathrm{mM}$ EDTA, $1 \mathrm{mM}$ EGTA, $150 \mathrm{mM} \mathrm{NaCl}, 1 \% \mathrm{NP} 40,1 \mathrm{mM} \mathrm{MgCl}$, $0.1 \%$ SDS, proteases inhibitors). Lysates were incubated with SA-agarose beads for $1 \mathrm{~h}$ at $4^{\circ} \mathrm{C}$ and centrifuged for $1 \mathrm{~min}$. Supernatants were discarded and beads were washed with the same buffer twice. Beads were resuspended in loading buffer $(100 \mathrm{mM}$ Tris $-\mathrm{HCl} \mathrm{pH} 6.8$, $4 \%$ SDS, $0.2 \%$ bromophenol blue, $20 \%$ glycerol, $200 \mathrm{mM}$ $\beta$-mercaptoethanol, 1mM DTT) as well as aliquots of total fractions ( $4 \%$ total lysate volume). Samples were boiled for 5 min and analyzed by Western blot.

\section{Statistics}

Results were expressed as the mean \pm s.e.m. $p$ values were estimated using Student's T test (2 tails).

For supplementary methods see Additional file 3.

\section{Additional files}

Additional file 1: Figure S1. Mut-GFP is not activated after $15 \mathrm{~min}$ of stimulation. HeLa cells were transfected with Mut-GFP (A) or IR-B-GFP (B) and after overnight starvation they were stimulated with $100 \mathrm{nM}$ rhlns for 5 or $15 \mathrm{~min}$ and fixed. Immunofluorescence assays were performed with anti-phospho-tyrosine (P99) and a secondary antibody conjugated with Cy3. Scale bars: $10 \mu \mathrm{m}$.

Additional file 2: Figure S2. Effect of the temperature in the internalization during labeling and CoA-biotin labeling. A. HeLa cells expressing IR-B were labeled with BAC-Ins and QD655 at room temperature or at $15^{\circ} \mathrm{C}$, fixed and imaged by confocal microscopy. Images were quantified as described in experimental section and the percentage of internalization was calculated. Results are expressed as the mean \pm s.e.m. B. HEK293 cells expressing Mut-GFP were incubated with

$1 \mu \mathrm{M}$ CoA-biotin with or without $2 \mu \mathrm{M}$ ACP-S and then labeled with 1 nM SA-550. Fixed cells were imaged by wide field microscopy. Scale bars: $5 \mu \mathrm{m}$.

Additional file 3: Supplemental Experimental Procedures.

Additional file 4: Figure S3. Effect of expression level on the internalization. Quantification of BAC-Ins-QD655 internalization was performed in cells co-expressing Mut and IR-B after $30 \mathrm{~min}$ at $37^{\circ} \mathrm{C}$ depending on the fluorescence levels of CoA-488. Cells were classified in high labeling (CoA-488>1600 cts) and low labeling (CoA-488<900 cts). Results are expressed as the mean \pm s.e.m. ( ${ }^{*}: p=0.01 ; n=8$ cells).
Additional file 5: Figure S4. Mut-GFP endocytosis over time. HeLa cells expressing Mut-GFP labeled with $0.2 \mu \mathrm{M} \mathrm{ACP-S}$ and $1 \mu \mathrm{M}$ CoA-532 were incubated with $50 \mathrm{nM} \mathrm{BAC-Ins}$ and $1 \mathrm{nM}$ QD655. Cells were incubated at $37^{\circ} \mathrm{C}$ for 15,45 or $150 \mathrm{~min}$ and then fixed. Samples were imaged by confocal microscopy. Scale bars: $10 \mu \mathrm{m}$.

Additional file 6: Figure S5. Mut effect on ERK1/2 activation. HeLa cells co-transfected with $0.1 \mu \mathrm{gg}$ pcDNA3-IR-B and different amounts of the mutant or EV were stimulated with $100 \mathrm{nM}$ rhlns for 5 min and assayed by Western blot. Quantification was performed by densitometry measuring phospho-ERK1/2 signal normalized to the basal $(*: p<0.05, n \geq 3)$. ' $p$ ' means phospho-antibodies. Results are expressed as the mean \pm s.e.m.

\section{Abbreviations}

ACP: Acyl carrier protein; ACP-S: Acyl carrier protein syntasa; BAC-Ins: Biotin amido caproyl insulin; BP: Band-pass; BSA: Bovine serum albumin; CoA: Coenzyme A; DMSO: Dimethyl sulfoxide; EV: Empty vector; FBS: Fetal bovine serum; FnIII-1: First Fibronectin type III domain; GFP: Enhanced green fluorescent protein; IGF: Insulin like growth factor; IGF-IR: Insulin like growth factor I receptor; IR: Insulin receptor; IR-A: Insulin receptor isoform A; IR-B: Insulin receptor isoform B; M: Manders coefficient; N.A.: Numerical aperture; PFA: Paraformaldehyde; QD: Quantum dot; rhIns: Recombinant human insulin; SCFP: Super cyan fluorescent protein; s.e.m.: Standard error from the mean; SYFP: Super yellow fluorescent protein; VFP: Visible fluorescent protein.

\section{Competing interests}

The authors declare that they have no competing interests.

\section{Authors' contributions}

$J G$ conceived the project, designed and performed all the experiments, analyzed the data and wrote the manuscript. EAJE conceived the project, designed the experiments and analyzed the data. FCL conceived the project, designed the experiments, analyzed the data, and wrote the manuscript. All authors read and approved the final manuscript with the exception of the deceased, Elizabeth A. Jares Erijman.

\section{Acknowledgements}

Elizabeth A Jares-Erijman died during manuscript preparation and we dedicate it to her memory. JG was awarded a CONICET doctoral fellowship and a short term EMBO fellowship. This work was supported by the Max Planck Society, UBA, CONICET and ANPCyT (Argentina). We thank Thomas M. Jovin and Donna J. Arndt-Jovin (Max Planck Institute for Biophysical Chemistry, Goettingen, Germany) for their help and support and for providing pBAD-ACPwt-S plasmid. We thank Laboratorios BETA (Argentina) for providing rhlns. We thank Anabella Srebrow and Omar Coso (IFYBINE, Argentina) for providing pAkt-HA and PAP-1-Luc plasmids. We thank Silvia Moreno (FCEN-UBA, Argentina) for her kind help with MALDI interpretation and Joachim Dichter for technical assistance.

\section{Author details}

1Departamento de Química Biológica, Facultad de Ciencias Exactas y Naturales (FCEN), Universidad de Buenos Aires (UBA) IQUIBICEN, CONICET, Intendente Güiraldes 2160, Ciudad Universitaria, C1428EGA Buenos Aires, Argentina. ${ }^{2}$ Departamento de Química Orgánica, FCEN UBA CIHIDECAR, CONICET, C1428EGA Buenos Aires, Argentina. ${ }^{3}$ Departamento de Ciencias Básicas, Universidad Nacional de Luján, Buenos Aires, Argentina. ${ }^{4}$ Present address: Department of Pathology and Immunology, Baylor College of Medicine, One Baylor Plaza, Houston, TX 77030 USA.

Received: 22 April 2013 Accepted: 17 June 2013

Published: 27 June 2013

\section{References}

1. Ebina $Y$, Ellis L, Jarnagin $K$, Edery M, Graf L, Clauser E, Ou J, Masiarz F, Kan YW, Goldfine ID, et al: The human insulin receptor CDNA: the structural basis for hormone-activated transmembrane signaling. Cell 1985, 40:747-758.

2. Ullrich A, Bell JR, Chen EY, Herrera R, Petruzelli LM, Dull TJ, Gray A, Coussens L, Liao Y, Tsubokawa M, et al: Human insulin receptor and its relationship 
to the tyrosine kinase family of oncogenes. Nature (London) 1985, 313:756-761.

3. Frasca F, Pandini G, Scalia P, Sciacca L, Mineo R, Costantino A, Goldfine ID, Belfiore A, Vigneri R: Insulin receptor isoform A, a newly recognized, highaffinity insulin-like growth factor II receptor in fetal and cancer cells. Mol Cell Biol 1999, 19:3278-3288.

4. Mosthaf $L$, Vogt $B$, Haring HU, Ullrich A: Altered expression of insulin receptor types $A$ and $B$ in the skeletal muscle of non-insulin-dependent diabetes mellitus patients. Proc Natl Acad Sci USA 1991, 88:4728-4730.

5. Kellerer M, Sesti G, Seffer E, Obermaier-Kusser B, Pongratz DE, Mosthaf L, Häring HU: Altered pattern of insulin receptor isotypes in skeletal muscle membranes of type 2 (noninsulin-dependent) diabetic subjects. Diabetologia 1993, 36:628-632.

6. Benecke H, Flier JS, Moller DE: Alternatively spliced variants of the insulin receptor protein. Expression in normal and diabetic human tissues. J Clin Invest 1992, 89:2066-2070.

7. Anderson CM, Henry RR, Knudson PE, Olefsky JM, Webste NJ: Relative expression of insulin receptor isoforms does not differ in lean, obese, and noninsulin-dependent diabetes mellitus subjects. J Clin Endocrinol Metab 1993, 76:1380-1382.

8. Hansen T, Bjørbaek C, Vestergaard H, Grønskov K, Bak JF, Pedersen O: Expression of insulin receptor spliced variants and their functional correlates in muscle from patients with non-insulin-dependent diabetes mellitus. J Clin Endocrinol Metab 1993, 77:1500-1505.

9. Sciacca L, Costantino A, Pandini G, Mineo R, Frasca F, Scalia P, Sbraccia P, Goldfine ID, Vigneri R, Belfiore A: Insulin receptor activation by IGF-II in breast cancers: evidence for a new autocrine/paracrine mechanism. Oncogene 1999, 18:2471-2479.

10. Pandini G, Frasca F, Mineo R, Sciacca L, Vigneri R, Belfiore A: Insulin/insulinlike growth factor I hybrid receptors have different biological characteristics depending on the insulin receptor isoform involved. J Biol Chem 2002, 277:39684-39695.

11. Pandini G, Vigneri R, Costantino A, Frasca F, Ippolito A, Fujita-Yamaguchi $Y$, Siddle K, Goldfine ID, Belfiore A: Insulin and insulin-like growth factor-I (IGF-I) receptor overexpression in breast cancers leads to insulin/IGF-I hybrid receptor overexpression: evidence for a second mechanism of IGF-I signaling. Clin Cancer Res 1999, 5:1935-1944.

12. Vella V, Pandini G, Sciacca L, Mineo R, Vigneri R, Pezzino V, et al: A novel autocrine loop involving IGF-II and the insulin receptor isoform-A stimulates growth of thyroid cancer. J Clin Endocrinol Metab 2002, 87:245-254.

13. Mosthaf L, Grako K, Dull TJ, Coussens L, Ullrich A, Mc Clain DA: Functionally distinct insulin receptors generated by tissue-specific alternative splicing. EMBO J 1990, 9:2409-2413.

14. Yamaguchi Y, Flier JS, Benecke H, Ransil BJ, Moller DE: Ligand-binding properties of the two isoforms of the human insulin receptor. Endocrinology 1993, 132:1132-1138.

15. Yamaguchi Y, Flier JS, Yokota A, Benecke H, Backer JM, Moller DE: Functional properties of two naturally occurring isoforms of the human insulin receptor in Chinese hamster ovary cells. Endocrinology 1991, 129:2058-2066.

16. Knudsen L, De Meyts $P$, Kiselyov W: Insight into the molecular basis for the kinetic differences between the two insulin receptor isoforms. Biochem J 2011, 440:397-403.

17. Morcavallo A, Genua M, Palummo A, Kletvikova E, Jiracek J, Brzozowski AM Iozzo RV, Belfiore A, Morrione A: Insulin and insulin-like growth factor II differentially regulate endocytic sorting and stability of insulin receptor isoform A. J Biol Chem 2012, 287:11422-11436.

18. Benyoucef $\mathrm{S}$, Surinya $\mathrm{KH}$, Hadaschik D, Siddle K: Characterization of insulin/ IGF hybrid receptors: contributions of the insulin receptor L2 and Fn1 domains and the alternatively spliced exon 11 sequence to ligand binding and receptor activation. Biochem J 2007, 403:603-613.

19. Smith U, Gale EA: Does diabetes therapy influence the risk of cancer? Diabetologia 2009, 52:1699-1708.

20. Will JC, Galuska DA, Vinicor F, Calle EE: Colorectal cancer: another complication of diabetes mellitus? Am J Epidemiol 1998, 147:816-825.

21. Hemkens LG, Grouven U, Bender R, Günster C, Gutschmidt S, Selke GW, Sawicki PT: Risk of malignancies in patients with diabetes treated with human insulin or insulin analogues: a cohort study. Diabetologia 2009, 52:1732-1744

22. Slieker LJ, Brooke GS, Di Marchi RD, Flora DB, Green LK, Hoffmann JA, Long $H B$, Fan L, Shields JE, Sundell KL, et al: Modifications in the B10 and B26-
30 regions of the $B$ chain of human insulin alter affinity for the human IGF-I receptor more than for the insulin receptor. Diabetologia 1997, 40(Suppl 2):S54-S61.

23. Kurtzhals P, Schäffer L, Sørensen A, Kristensen C, Jonassen I, Schmid C, Trub $\mathrm{T}$ : Correlations of receptor binding and metabolic and mitogenic potencies of insulin analogs designed for clinical use. Diabetes 2000 49:999-1005.

24. Hansen BF, Danielsen GM, Drejer K, Sørensen AR, Wiberg FC, Klein HH, Lundemose AG: Sustained signalling from the insulin receptor after stimulation with insulin analogues exhibiting increased mitogenic potency. Biochem J 1996, 315(Pt 1):271-279.

25. Chang $L$, Chiang $S H$, Saltiel AR: Insulin signaling and the regulation of glucose transport. Mol Med 2004, 10:65-71.

26. Murphy JE, Padilla BE, Hasdemir B, Cottrell GS, Bunnett NW: Endosomes: a legitimate platform for the signaling train. Proc Natl Acad Sci USA 2009, 106:17615-17622.

27. Whitmarsh AJ, Davis RJ: Transcription factor AP-1 regulation by mitogenactivated protein kinase signal transduction pathways. J Mol Med (Berl) 1996, 74:589-607.

28. Karin M, Liu Z, Zandi E: AP-1 function and regulation. Curr Opin Cell Biol 1997, 9:240-246.

29. Treisman R: Regulation of transcription by MAP kinase cascades. Curr Opin Cell Biol 1996, 8:205-215.

30. Zhou Z, Cironi P, Lin AJ, Xu Y, Hrvatin S, Golan DE, Silver P, Walsh CT, Yin J: Genetically encoded short peptide tags for orthogonal protein labeling by Sfp and AcpS phosphopantetheinyl transferases. ACS Chemical Biology 2007, 2:337-334

31. Giudice J, Jares-Erijman EA, Leskow FC: Endocytosis and intracellular dissociation rates of human insulin-insulin receptor complexes by quantum dots in living cells. Bioconjug Chem 2013, 24:431-442.

32. Giudice J, Barcos LS, Guaimas FF, Penas-Steinhardt A, Giordano L, JaresErijman EA, Coluccio Leskow F: Insulin and insulin like growth factor II endocytosis and signaling via insulin receptor B. Cell Commun Signal 2013, 11:18.

33. McKern NM, Lawrence MC, Streltsov VA, Lou MZ, Adams TE, Lovrecz GO, Elleman TC, Richards KM, Bentley JD, Pilling PA, et al: Structure of the insulin receptor ectodomain homodimer reveals an unexpected foldedover arrangement of the $\mathrm{N}$ - and C-terminal halves. Nature 2006 443:218-221.

34. Menting JG, Whittaker J, Margetts MB, Whittaker LJ, Kong GK, Smith BJ, Watson CJ, Záková L, Kletvíková E, Jiráček J, et al: How insulin engages its primary binding site on the insulin receptor. Nature 2013, 493:241-245.

35. Lidke DS, Nagy P, Heintzmann R, Arndt-Jovin DJ, Post J, Grecco H, JaresErijman EA, Jovin TM: Quantum dot ligands reveal EGFR dynamics in living cells. Nat Biotechnol 2004, 22:198-203.

36. Wilden PA, Siddle K, Haring E, Backer JM, White MF, Kahn CR: The role of insulin receptor kinase domain auto-phosphorylation in receptormediated activities. Analysis with insulin and anti-receptor antibodies. J Biol Chem 1992, 267:13719-13727.

37. Bergeron JJ, Di Guglielmo GM, Baass PC, Authier F, Posner BI: Endosomes, receptor tyrosine kinase internalization and signal transduction. Biosci Rep 1995, 15:411-418.

38. Biener $Y$, Feinstein R, Mayak M, Kaburagi $Y$, Kadowaki T, Zick Y: Annexin II is a novel player in insulin signal transduction Possible association between annexin II phosphorylation and insulin receptor internalization. J Biol Chem 1996, 271:29489-29496.

39. Grimes ML, Zhou J, Beattie EC, Yuen EC, Hall DE, Valletta JS, Topp KS, LaVail $\mathrm{JH}$, Bunnett NW, Mobley WC: Endocytosis of activated TrkA: Evidence that nerve growth factor induces formation of signaling endosomes. J Neurosci 1996, 16:7950-7964.

40. Youngren JF: Regulation of insulin receptor function. Cell Mol Life Sci 2007, 64:873-891.

41. Cann AD, Kohanski RA: Cis-autophosphorylation of juxtamembrane tyrosines in the insulin receptor kinase domain. Biochemistry 1997, 36:7681-7689

42. Takata Y, Webster NJ, Olefsky JM: Mutation of the two carboxyl-terminal tyrosines results in an insulin receptor with normal metabolic signaling but enhanced mitogenic signaling properties. J Biol Chem 1991, 266:9135-9139.

43. Ando A, Momomura K, Tobe K, Yamamoto-Honda R, Sakura H, Tamori Y, Kaburagi Y, Koshio O, Akanuma Y, Yazaki Y, et al: Enhanced insulin-induced 
mitogenesis and mitogen-activated protein kinase activities in mutant insulin receptors with substitution of two $\mathrm{COOH}$-terminal tyrosine autophosphorylation sites by phenylalanine. J Biol Chem 1992, 267:12788-12796

44. Frattali AL, Pessin JE: Relationship between a subunit ligand occupancy and $\beta$ subunit autophosphorylation in insulin / insulin-like growth factor-1 hybrid receptor. J Biol Chem 1993, 268:7393-7400.

45. Ceresa BP, Kao AW, Santeler SR, Pessin JE: Inhibition of clathrin mediated endocytosis selectively attenuates specific insulin receptor signal transduction pathways. Mol Cell Biol 1998, 18:3862-3870.

46. Hamer I, Foti M, Emkey R, Cordier-Bussat M, Philippe J, De Meyts P, Maeder C, Kahn CR, Carpentier JL: An arginine to cysteine (252) mutation in insulin receptors from a patient with severe insulin resistance inhibits receptor internalization but preserves signalling events. Diabetologia 2002, 45:657-667.

47. Jensen $M$, De Meyts P: Molecular mechanisms of differential intracellular signaling from the insulin receptor. Vitam Horm 2009, 80:51-75.

doi:10.1186/1478-811X-11-45

Cite this article as: Giudice et al:: Insulin receptor membrane retention by a traceable chimeric mutant. Cell Communication and Signaling 2013 11:45

\section{Submit your next manuscript to BioMed Central and take full advantage of:}

- Convenient online submission

- Thorough peer review

- No space constraints or color figure charges

- Immediate publication on acceptance

- Inclusion in PubMed, CAS, Scopus and Google Scholar

- Research which is freely available for redistribution 